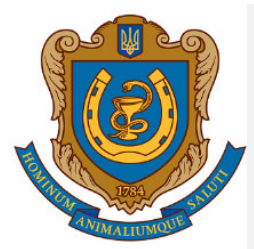

Ukrainian Journal of

Veterinary and Agricultural Sciences

http://ujvas.com.ua

\title{
Dynamics of individual indicators of protein metabolism in the body of broiler chickens on the background of combined stress when included in the diet "Reasil Humic Vet" + "Laktin" and "Reasil Humic Health"
}

\author{
V. G. Stoyanovskyy, M. O. Shevchuk, I. A. Kolomiiets, V. A. Kolotnytskyy \\ Stepan Gzhytskyi National University of Veterinary Medicine and Biotechnologies, Pekarska Str., 50, Lviv, 79010, Ukraine
}

\begin{tabular}{l} 
Article info \\
Received 06.04.2020 \\
Received in revised form \\
11.05 .2020 \\
Accepted 12.05.2020 \\
\hline Correspondence author \\
Iryna Kolomiiets \\
Tel.: +38-067-112-41-45 \\
E-mail: kolomieciryna@gmail.com
\end{tabular}

2020 Stoyanovskyy $\mathrm{V}$, et al. This is an open-access article distributed under the terms of the Creative Commons Attribution License, which permits unrestricted use, distribution, and reproduction in any medium, provided the original author and source are credited.

\section{$(\mathrm{cc}) \mathrm{BY}$}

Contents

1. Introduction

2. Materials and methods

3. Results and discussion

4. Conclusions .....

References

\begin{abstract}
The body of broiler chickens is characterized by a high metabolism, which promotes rapid growth and development, but their performance indicators are largely related to housing conditions, which are known to include a number of technological stressors. With the development of stress in the body of poultry changes the course of metabolic processes, which causes changes in all types of metabolism, including protein. The aim of the study was to determine the changes in individual indicators of protein metabolism in the body of broiler chickens against the background of combined stress when included in the diet "Reasil Humic Vet" + "Laktin" and "Reasil Humic Health". At 13th day of life, all clinically healthy poultry were exposed to combined stress - revaccination (intranasal Newcastle disease) plus cold stress (for 60 minutes by air conditioning and $5{ }^{\circ} \mathrm{C}$ in the vivarium). Material for research was selected for 3 days after the action of the stress factor (stage of anxiety), 13, 20 and 26 days after the action of the stress factor (the resistance stage). The material for the study was blood plasma, which determined the concentration of total protein, as well as the content of albumin, globulin fraction $(\alpha 1, \alpha 2, \beta, \gamma)$. It was found that 3 days after the action of stress in chickens of Control group the development of adaptive reactions is manifested by the stability of the total protein content and redistribution of the fractional composition of plasma globulins in the form of increased albumin and $\alpha 2$-globulins. At different stages of development of the stage of resistance in birds of Control group, the content of total protein decreases by an average of $14.6 \%$ due to the content of albumin by $6.9 \%$ and $\alpha 2$-globulins - by $15.9 \%$, against the background of increasing $\alpha 1-$ and $\gamma$ globulins by 23.1 and $33.5 \%$ with the stabilization of individual studied indicators at the final stages of development of the resistance stage. The use in the diet of broilers feed "Reasil Humic Vet", probiotic feed supplement "Laktin", feed "Reasil Humic Health" under the influence of complex stress helps to increase the intensity of protein metabolism in poultry with the development of adaptation syndrome, as evidenced by the growth of total protein on average by $37.8 \%(\mathrm{P}<0.05)$ and albumin - by $17.0 \%(\mathrm{P}<0.05)$, which indicates an increase in the intensity of protein-synthesizing properties of the organism. In different periods of stress in the blood of broiler chickens Research groups there is an increase in the ratio of individual protein fractions, especially the content of $\gamma$-globulins - an average of $21.3 \%(\mathrm{P}<0.05)$, which indicates an increase in the immune status of their body with a predominance of numerical values in the Research 1 group of poultry.
\end{abstract}

Key words: broiler chickens, vaccination, cold stress, adaptation, proteins, globulins, humic acids, probiotic.

\section{Citation:}

Stoyanovskyy, V. G., Shevchuk, M. O., Kolomiiets, I. A., \& Kolotnytskyy, V. A. (2020). Dynamics of individual indicators of protein metabolism in the body of broiler chickens on the background of combined stress when included in the diet "Reasil Humic Vet" + "Laktin" and "Reasil Humic Health". Ukrainian Journal of Veterinary and Agricultural Sciences, 3(2), 42-46.

\section{Introduction}

In poultry farming in many countries around the world in order to meet the growing needs of the population in quality and nutritious food is profitable to breed broiler chickens (Virden \& Kidd, 2009). The body of this species of poultry is characterized by a high metabolism, which promotes rapid growth and development, but their performance indicators are largely related to housing conditions, which are known to include a number of technological stressors (Tsiouris et al., 2015). With the development of stress in the body of poultry changes the course of metabolic processes, which causes changes in all types of metabolism, including protein (Tóthová et al., 2019; Sobolev et al., 2019; Sobolieva et al.,
2020). Since the protein content in the blood and the ratio of its fractions are characterized by fairly constant values, but are in continuous dynamic equilibrium with the protein composition of body tissues and can change significantly under stress factors, changes in their composition are considered biomarkers of factors of various etiologies (Erol et al., 2017).Therefore, the study of metabolic processes in broiler chickens with the development of adaptation syndrome, as well as the development of sound approaches to increase their productivity and search for ways to improve the safety of poultry is a challenge today and remains one of the most important issues in research (Pavlova, 2015; Kovalenko et al., 2020). The aim of the study was to determine the changes in individual indicators 
of protein metabolism in the body of broiler chickens against the background of combined stress when included in the diet "Reasil Humic Vet" + "Laktin" and "Reasil Humic Health".

\section{Materials and methods}

All manipulations with chickens were carried out in compliance with the requirements of the European Convention for the Protection of Vertebrate Animals Used for Experimental and Scientific Purposes (Strasbourg, 1986), the First National Congress on Bioethics (Kyiv, 2001) - "General Ethical Principles of Animal Experiments" and in compliance with the principles of humanity set out in the European Community Directive. The experiment was conducted on the basis of the vivarium of the State Research Control Institute of Veterinary Drugs and Feed Additives at young broiler chickens of cross "Kobb-500", of which at 5 days of age formed three groups - control (C) and two experimental (R1, R2 ) 25 individuals in each group, selected on the principle of analogues. Prior to the experiment, all poultry were vaccinated against Marek's disease, Newcastle disease and infectious bronchitis according to the timing of the respective vaccinations. Poultry keeping met the generally accepted technological requirements of floor keeping with free access to drinkers and feeders. From 11 days of life and until the end of the experiment ( 45 days of life) in addition to the standard diet of chickens R1 group was fed with feed material "Reasil Humic Vet" in liquid form at the rate of $100 \mathrm{ml} / 100$ liters of water and probiotic feed additive "Laktin" at the rate of 1-2 1/100 1 of water; chickens of group R2 were fed with the feed preparation "Reasil Humic Health" in dry form at the rate of $1-2 \mathrm{~kg} / 1$ ton of feed according to the instructions. At 13 th day of life, all clinically healthy poultry were exposed to combined stress - revaccination (intranasal Newcastle disease) plus cold stress (for 60 minutes by air conditioning and $5{ }^{\circ} \mathrm{C}$ in the vivarium). Material for research was selected for 3, 13, 20 and 26 days after the action of the stress factor: these periods of implementation of stress reactions are proposed on the basis of research and development of the Department of Normal and Pathological Physiology named after S. V. Stoyanovsky (Stojanovskij et al., 2012; Stojanovskij et al., 2018). Slaughter was performed before morning feeding after light ether anesthesia by decapitation of 5 chickens from each group. The material for the study was blood plasma, which determined the concentration of total protein, as well as the content of albumin, globulin fraction $(\alpha 1, \alpha 2, \beta, \gamma)$ by conventional methods (Vlizlo et al., 2012).

\section{Results and discussion}

In the study of general physiological parameters in the initial stages of the combined stress was observed suppression of the general condition of young poultry, which was manifested by their accumulation, a decrease in feed consumption, which lasted until the end of the first day. The results of the study of the content of protein and its fractions in the blood plasma of broiler chickens under the action of stress on the background of the inclusion in the diet of supplements are shown in table 1.

\section{Table 1}

Indicators of metabolism of blood proteins of broiler chickens against the background of combined stress when included in the diet of "Reasil Humic Vet" + "Laktin" and "Reasil Humic Health" $(M \pm m, n=5)$

\begin{tabular}{|c|c|c|c|c|}
\hline Groups & $\begin{array}{c}3 \text { days after exposure } \\
\text { to stress }\end{array}$ & $\begin{array}{c}13 \text { days after exposure to } \\
\text { stress }\end{array}$ & $\begin{array}{c}20 \text { days after exposure } \\
\text { to stress }\end{array}$ & $\begin{array}{c}26 \text { days after exposure } \\
\text { to stress }\end{array}$ \\
\hline \multicolumn{5}{|c|}{ The content of total protein, $\mathrm{g} / \mathrm{l}$} \\
\hline $\mathrm{C}$ & $24.55 \pm 3.71$ & $21.82 \pm 3.11$ & $17.45 \pm 1.90$ & $25.43 \pm 3.77$ \\
\hline $\mathrm{R}_{1}$ & $24.71 \pm 2.88$ & $21.11 \pm 2.48$ & $24.41 \pm 2.11 *$ & $36.41 \pm 2.31 *$ \\
\hline $\mathrm{R}_{2}$ & $24.63 \pm 2.94$ & $24.70 \pm 2.74$ & $24.05 \pm 2.20 *$ & $24.06 \pm 3.11$ \\
\hline \multicolumn{5}{|c|}{ Albumin content, $\%$} \\
\hline $\mathrm{C}$ & $36.01 \pm 1.58$ & $33.53 \pm 1.76$ & $34.90 \pm 1.15$ & $35.11 \pm 1.14$ \\
\hline $\mathrm{R}_{1}$ & $38.82 \pm 2.84$ & $39.22 \pm 1.39^{*}$ & $31.73 \pm 2.94$ & $40.80 \pm 1.31 *$ \\
\hline $\mathrm{R}_{2}$ & $41.32 \pm 1.60 *$ & $33.90 \pm 2.10$ & $29.94 \pm 1.33 *$ & $37.21 \pm 2.10$ \\
\hline \multicolumn{5}{|c|}{ The content of $\alpha 1$-globulins, $\%$} \\
\hline $\mathrm{C}$ & $6.10 \pm 0.74$ & $7.51 \pm 0.60$ & $6.47 \pm 0.79$ & $4.80 \pm 0.44$ \\
\hline $\mathrm{R}_{1}$ & $7.95 \pm 0.93$ & $5.05 \pm 0.57^{*}$ & $5.38 \pm 0.54$ & $3.65 \pm 0.80$ \\
\hline $\mathrm{R}_{2}$ & $3.29 \pm 0.58 * *$ & $6.80 \pm 0.86$ & $4.94 \pm 0.61^{*}$ & $3.57 \pm 0.47$ \\
\hline \multicolumn{5}{|c|}{ The content of $\alpha 2$-globulins, $\%$} \\
\hline $\mathrm{C}$ & $26.81 \pm 1.95$ & $22.54 \pm 2.72$ & $21.42 \pm 3.37$ & $23.81 \pm 3.48$ \\
\hline $\mathrm{R}_{1}$ & $26.90 \pm 3.08$ & $21.66 \pm 3.44$ & $20.71 \pm 2.95$ & $18.95 \pm 2.28$ \\
\hline $\mathrm{R}_{2}$ & $20.32 \pm 1.79 *$ & $21.91 \pm 2.17$ & $22.08 \pm 2.56$ & $20.36 \pm 2.30$ \\
\hline \multicolumn{5}{|c|}{ The content of $\beta$-globulins, $\%$} \\
\hline $\mathrm{C}$ & $17.56 \pm 1.11$ & $17.63 \pm 1.06$ & $19.41 \pm 1.06$ & $18.39 \pm 1.56$ \\
\hline $\mathrm{R}_{1}$ & $13.27 \pm 1.17^{*}$ & $13.50 \pm 1.08^{*}$ & $21.50 \pm 2.42$ & $15.35 \pm 1.04$ \\
\hline $\mathrm{R}_{2}$ & $15.48 \pm 1.86$ & $16.19 \pm 1.21$ & $23.24 \pm 2.18$ & $18.28 \pm 1.55$ \\
\hline \multicolumn{5}{|c|}{ The content of $\gamma$-globulins, $\%$} \\
\hline $\mathrm{C}$ & $13.41 \pm 1.55$ & $18.69 \pm 1.06$ & $17.90 \pm 1.22$ & $17.25 \pm 1.57$ \\
\hline $\mathrm{R}_{1}$ & $13.10 \pm 1.16$ & $20.70 \pm 2.27$ & $21.02 \pm 1.23^{*}$ & $21.71 \pm 1.01 *$ \\
\hline $\mathrm{R}_{2}$ & $19.82 \pm 1.44^{*}$ & $21.61 \pm 1.15$ & $18.92 \pm 1.88$ & $20.76 \pm 2.45$ \\
\hline
\end{tabular}

Note: the differences are statistically significant in relation to group $\mathrm{C}$ and are marked: ${ }^{*} \mathrm{P}<0.05 ; *_{-} \mathrm{P}<0.01 ; *^{*} *_{-} \mathrm{P}<0.001$ 
While analyzing the data, it should be noted that in the blood of chickens of $\mathrm{C}, \mathrm{R} 1$ and $\mathrm{R} 2$ groups in 3 days after exposure to stress, which corresponded to the stage of anxiety, the total protein content was within $24.63 \pm 2.94 \mathrm{~g} / \mathrm{l}$, which corresponded to the physiological norm for this age of the poultry according to the literature (Saki et al., 2016). The content of albumin in the blood plasma of chickens of group $\mathrm{C}$ was $36.01 \pm 1.58 \%$, in chickens R1 and R2 of the group there was a tendency to increase their content with probable differences in the blood of poultry of group R2, which was $14.7 \%(\mathrm{P}<0.05)$ compared with the control.

It should be noted that the value of this indicator was the highest in comparison with the studied stress periods and in comparison with the R1 group of poultry, which indicated the strengthening of protein-synthetic processes in their body. The content of $\alpha 1$-globulins in chickens of group $\mathrm{C}$ was $6.10 \pm 0.74 \%$, in group R1 - slightly increased, and in group R2 there was a decrease in the value of this indicator by 1.9 times $(\mathrm{P}<0.05)$. With regard to the content of $\alpha 2-$ globulins, it was found that at the stage of anxiety, the value of this indicator was the highest, compared with the studied stages of stress, as well as in comparison with the R2 group of poultry. In particular, the content of $\alpha 2$-globulins in birds of group $\mathrm{C}$ and $\mathrm{R} 1$ was on average $26.81 \pm 1.95 \%$, and in chickens of group R2 was lower by $24.2 \%(\mathrm{P}<0.05)$ relative to control. The content of $\beta$-globulins in the blood of chickens of group $\mathrm{C}$ was $17.56 \pm 1.11 \%$, in young poultry of the experimental groups their decrease was detected, but within the statistical probability was their value in group R2 with a difference of $24.4 \%(\mathrm{P}<0.05)$. The content of $\gamma-$ globulins in chickens of group $\mathrm{C}$ and $\mathrm{R} 1$ was in the range of $13.41 \pm 1.55 \%$, while in broilers of group R2 it increased 1.5 times $(\mathrm{P}<0.05)$.

In the initial stages of the development of the resistance stage, which occurred on the 13th day after exposure to stress, in chickens $\mathrm{C}$ and $\mathrm{R} 1$ groups, the total protein content decreased to $21.11 \pm 2.48 \mathrm{~g} / \mathrm{l}$, which was $14.6 \%$ less than the anxiety stage. In poultry of group R2, the value of this indicator remained unchanged relative to the stage of anxiety and increased to $24.70 \pm 2.74 \mathrm{~g} / \mathrm{l}$ compared with control values. Apparently, due to hormonal adjustment of the body, which results in the mobilization of deposited carbohydrates, reduced breakdown of structural proteins of the body, enhanced gluconeogenesis, which could lead to a decrease in total protein in the blood of poultry of certain groups under stress (Nguyen et al., 2016). The main changes in the content of total protein in chickens of group $\mathrm{C}$ were due to a decrease in albumin by $6.9 \%$ and $\alpha 2$-globulins - by $15.9 \%$, which indicated a possible decrease in their synthesis in the liver, while the numerical values in the blood $\beta$ globulins in this period of development of the adaptation syndrome had no changes. With regard to $\alpha 1$-globulins, it should be noted that their content in the blood plasma of chickens of group $\mathrm{C}$ increased by $23.1 \%$ relative to the stage of anxiety, which was the highest in comparison with the studied stages of stress and in comparison with the experimental groups. At the 13th day after stress, the amount of $\gamma$-globulins in the blood of group $\mathrm{C}$ of chickens increased markedly by $39.4 \%$, which may be related to revaccination. In chickens of group R1, which were fed the feed product "Reasil Humic Vet" and probiotic feed additive "Laktin", 13 days after exposure to stress, a decrease in total protein due to $\alpha 1-, \alpha 2-, \beta$-globulins, and the difference in reduction of the obtained numerical indicators compared with the control was 1.5 times and 1.3 times, respectively $(\mathrm{P}<0.05)$. However, the obtained numerical differences were less significant in chickens of group R1, compared with the control, because there was a probable increase in albumin content (the difference with the control here was $17.0 \%(\mathrm{P}<0.05)$, as well as a tendency to increase $\gamma$-globulins to $20.70 \pm$ $2.27 \%$. During this period, the content of albumin, $\alpha 1-, \alpha 2-$ globulins in the R2 group of birds fed Reasil Humic Health was at the level of control, the content of $\beta$-globulins was slightly reduced, but the content of $\gamma$-globulins increased to $21.61 \pm 1.15 \%$, which was the highest compared to other groups and indicated an increase in the activity of the immune system of their body during the development of the adaptation syndrome.

While analyzing the numerical values of table 1 , we can see that on the 20th day of the development of the resistance stage, the content of total protein and its fractions in the blood of chickens of all groups changed significantly. It is necessary to pay attention to the further decrease in the content of protein in the blood of poultry of group C; its amount here was $17.45 \pm 1.90 \mathrm{~g} / \mathrm{l}$, which was $28.9 \%$ less than the stage of anxiety. Our results do not fully agree with the literature, which states that due to increased amino acid catabolism due to glucocorticoids in the blood plasma of poultry, the concentration of total protein increases due to the redistribution of albumin between blood and tissues (Tsiouris et al., 2015). During this critical period, the content of albumins and $\alpha 2$-globulins remained lower by 3.1 and $20.1 \%$, and there was no dynamics of changes in the content of $\alpha 1$-globulins in the blood of poultry of group $C$ : the obtained numerical values approached the value of the alarm stage. The content of $\beta$ - and $\gamma$-globulins in the blood of group $\mathrm{C}$ chickens was characterized by a tendency to increase by 10.5 and $33.5 \%$, respectively, compared with the anxiety stage. In poultry of group $\mathrm{R} 1$, the protein content was $24.41 \pm 2.11 \mathrm{~g} / \mathrm{l}$, which was higher than the control by $39.9 \%(\mathrm{P}<0.05)$.

The content of $\gamma$-globulins increased to $21.02 \pm 1.23 \%$, which was $21.3 \%(\mathrm{P}<0.05)$ higher than the control. The content of $\alpha 1-, \alpha 2$-globulin albumins here was lower than the control by an average of $4.1 \%$, as well as lower than those at the stage of anxiety, but the decrease in numerical values was smaller compared to the control. The content of $\beta$-globulins in the blood of poultry of group R1 did not differ significantly from the numerical values obtained for group $\mathrm{C}$, but there was a tendency to increase their content. Under the condition of feeding the feed product "Reasil Humic Health" chickens of group R2 revealed an increase in protein content to $25.41 \pm 2.20 \mathrm{~g} / \mathrm{l}$, which was higher by $37.8 \%(\mathrm{P}<0.05)$ compared with the control mainly for due to $\alpha 2-, \beta$-globulins. It should be noted that the value of the content of $\beta$-globulins was the highest, compared with the studied stages of stress and in comparison with the R1 group of poultry. However, the content of albumin here was $29.94 \pm 1.33 \%$, which was $14.2 \%(\mathrm{P}<0.05)$ less than the control and significantly lower than the stage of anxiety, and the content of $\alpha 1$-globulins decreased by $23.6 \%(\mathrm{P}<0.05)$ compared with those in poultry of group C. With regard to the fraction of $\gamma$-globulins, it was found that their content approached the value of the numerical value in the blood of poultry at the stage of alarm, and was not significantly higher than the control values and was $18.92 \pm 1.88 \%$. The obtained results indicate a positive effect of the additives used, which increase the intensity of protein metabolism and 
redistribution of its fractions in the body of chickens of experimental groups with a predominance in the R1 group of poultry.

While analyzing the dynamics of changes in protein metabolism on the 26th day of the development of the stage of resistance in chickens of group $\mathrm{C}$ the stabilization of some of the studied indicators was revealed. First of all, the protein content approached the value of the anxiety stage, which was $25.43 \pm 3.77 \mathrm{~g} / 1$, but the content of albumin, $\alpha 1-$, $\alpha 2$-globulins decreased by 1.0, 1.6 and 1.1 times, respectively. There was a slight increase in the content of $\beta$-globulins, compared with the stage of anxiety, and the content of $\gamma$ globulins increased to $17.25 \pm 1.57 \%$ and exceeded this figure by $28.6 \%$ relative to the stage of anxiety. This redistribution of protein fractions could be due to the peculiarities of the development of adaptive-compensatory reactions in the body of poultry of group C. Studies have shown that in poultry of group R1 on the 26th day of development of the resistance stage there was an increase in protein content to $36.41 \pm 2.31 \mathrm{~g} / 1$ (the difference with the control here was $43.2 \%(\mathrm{P}<0.05)$. It should be noted that the value of this indicator was the highest in comparison with the studied periods of stress and in comparison with the R2 group of poultry, which indicated a positive effect of additives on the intensity of protein metabolism in chickens. Studies of the fractional composition of plasma globulins of chickens of group R1 showed a positive dynamics of albumin, $\beta$ - and $\gamma$ globulins, compared with the stage of anxiety, which was $5.1 \%, 15.6 \%$ and $65.7 \%$, respectively. During this period, the albumin content was higher by $16.2 \%(\mathrm{P}<0.05)$, compared with the control. There was a tendency to decrease the content of $\alpha 1-, \alpha 2-, \beta$-globulins in the blood of chickens of group R1 (the difference with the control here was $23.9 \%$, $20.4 \%$ and $16.5 \%$ ), but probable intergroup differences in the obtained numerical values for in relation to control was not detected. The highest numerical values of the content of $\gamma$-globulins in poultry of group R1 in comparison with all periods of stress were also established, and in relation to the control the difference was $25.9 \%(\mathrm{P}<0.05)$. The results indicate that the use in the diet of broiler chickens feed "Reasil Humic Vet" and probiotic feed additive "Laktin" under the influence of complex stress adaptation processes in their body take place in the form of redistribution of different protein fractions, a slight increase in catabolic processes against the background of increased synthetic liver function and activity of the immune system. Under the condition of feeding the feed preparation "Reasil Humic Health" to poultry of group R2 on the 26th day of the development of the resistance stage, the protein content was $24.06 \pm 3.11 \mathrm{~g} / \mathrm{l}$, which was $5.4 \%$ less than the control, and approached the digital values stage of anxiety. During this period, the albumin content was higher by $6.0 \%$ compared to the control, however, the value of the obtained indicator remained lower relative to the stage of anxiety. There was a decrease in the content of $\alpha 1$-, $\alpha 2$-globulins by $25.6 \%$ and $14.5 \%$ in chickens of group R2 without significant intergroup differences in relation to the control; their numerical values remained at the level of the alarm stage. Studies of the fractional composition of plasma globulins of chickens of group R2 showed a positive dynamics of the content of $\beta$ and $\gamma$-globulins, compared with the stage of anxiety, which was $18.1 \%$ and $4.7 \%$, respectively. It should be noted that the numerical value of the content of $\beta$-globulins here was close to control, and the content of $\gamma$-globulins increased by
$20.3 \%$ compared to the control, without significant intergroup differences, which could indicate an increase in protein synthesis in their body and increase immune activity systems.

\section{Conclusions}

It was found that 3 days after the action of stress in chickens of group $\mathrm{C}$ the development of adaptive reactions is manifested by the stability of the total protein content and redistribution of the fractional composition of plasma globulins in the form of increased albumin and $\alpha 2$-globulins. At different stages of development of the stage of resistance in birds of group $\mathrm{C}$, the content of total protein decreases by an average of $14.6 \%$ due to the content of albumin by $6.9 \%$ and $\alpha 2$-globulins - by $15.9 \%$, against the background of increasing $\alpha 1$ - and $\gamma$-globulins by 23.1 and $33.5 \%$ with the stabilization of individual studied indicators at the final stages of development of the resistance stage. The use in the diet of broilers feed "Reasil Humic Vet", probiotic feed supplement "Laktin", feed "Reasil Humic Health" under the influence of complex stress helps to increase the intensity of protein metabolism in poultry with the development of adaptation syndrome, as evidenced by the growth of total protein on average by $37.8 \%(\mathrm{P}<0.05)$ and albumin - by $17.0 \%(\mathrm{P}<0.05)$, which indicates an increase in the intensity of protein-synthesizing properties of the organism. In different periods of stress in the blood of broiler chickens $\mathrm{R} 1$ and R2 groups there is an increase in the ratio of individual protein fractions, especially the content of $\gamma$-globulins - an average of $21.3 \%(\mathrm{P}<0.05)$, which indicates an increase in the immune status of their body with a predominance of numerical values in the R1 group of poultry.

Prospects for further research are seen in the studied states of immunological reactivity of broiler chickens at different stages of stress for the inclusion in the diet of feed additives "Reasil Humic Vet" + "Laktin" and feed additive "Reasil Humic Health".

\section{Conflict of interest}

The authors declare that there is no conflict of interest.

\section{References}

Erol, H. S., Imik, H., Gumus, R., \& Halici, M. (2017). The Effects of Different Amount of Protein and Vitamin E Supplementation in Rations on Lipid and Antioxidant Metabolism of Broilers Exposed to Heat Stress. Brazilian Journal of Poultry Science, 19(2), 289-296.doi: 10.1590/1806-9061-2016-0404.

Kovalenko, A. M., Tkachev, A. V., Tkacheva, O. L., Gutyj, B. V., Prystupa, O. I., Kukhtyn, M. D., Dutka, V. R., Veres, Ye. M., Dashkovskyy, O. O., Senechyn, V. V., Riy, M. B., \& Kotelevych, V. A. (2020). Analgesic effectiveness of new nanosilver drug. Ukrainian Journal of Ecology, 10(1), 300306. doi: $10.15421 / 202047$.

Nguyen, P. H., Greene, E., Donoghue, A., Huff, G., Clark, F. D., \& Dridi, S. (2016). A new insight into cold stress in poultry production. Adv. Food. Technol. Nutr. Sci. Open. J., 2(1), 1-2. doi: 10.17140/AFTNSOJ-2-124.

Pavlova, I. (2015). Effect of probiotics on doxycycline disposition in gastro-intestinal tract of poultry. Bulgarian Journal of Veterinary Medicine, 18(3), 248-257. doi: 10.15547/bjvm.908.

Saki, A. A., Maleckey, M., Johari, R., Goudarzi, S. M., \& Abdolmaleki, M. (2016). The effects of protein, amino acid, and dietary electrolyte balance on broiler chicken performance 
and blood parameters under heat stress. Acta Sci., Anim. Sci., 38(3), 111-118. doi: 10.4025/actascianimsci.v38i3.30747.

Sobolev, O. I., Gutyj, B. V., Sobolieva, S. V. ... Leskiv, K. Y., \& Guta, Z. A. (2019). Chemical composition, energy and biological value of broiler chicken meat caused by various doses of selenium. Ukrainian Journal of Ecology, 9(4), 622627. https://www.ujecology.com/articles/chemical-composition -energy-and-biological-value-of-broiler-chicken-meat-causedby-various-doses-of-selenium.pdf.

Sobolieva, S. V., Gutyj, B. V., \& Sobolev, O. I. (2020). Changes in goslings' blood pattern under the influence of different doses additives of selenium in forages. Scientific Messenger of Lviv National University of Veterinary Medicine and Biotechnologies. Series: Agricultural sciences, 22(92), 50-55. doi: 10.32718/nvlvet-a9209.

Stojanovskij, V. G., Kolomiiets, I. A., Kamratska, O. I., \& Kolontytskij, V. A. (2012). Fiziologichnij stan organizmu kurchat-brojleriv u kritichni vikovi periodi pri zastosuvanni imunokoregujuchih preparativ na tli vakcinacii. Naukovyi visnyk LNUVMB imeni S. Z. Gzhytskoho, 14, 2(53), 236-239 (in Ukrainian).
Stojanovskij, V. G., Kolomiec, I. A., Garmata, L. S., \& Kamracka, O. I. (2018). Zmini morfofunkcionalnogo stanu organiv endokrinnoi ta imunnoi sistem perepeliv promislovogo viroshhuvannja za dii stresu. Fiziologichnij zhurnal, 64(1), 2533. doi: 10.15407/fz64.01.025 (in Ukrainian).

Tóthová, C., Sesztáková, E., Bielik, B., \& Nagy, O. (2019). Changes of total protein and protein fractions in broiler chickens during the fattening period. Vet World, 12(4), 598-604. doi: 10.14202/vetworld.2019.598-604.

Tsiouris, V., Georgopoulou, I., Batzios, C., Pappaioannou, N., Ducatelle R., \& Fortomaris P. (2015). The effect of cold stress on the pathogenesis of necrotic enteritis in broiler chicks. Avian Pathology, 44(6), 430-435, doi: 10.1080/03079457.2015.1083094.

Virden, W. S., \& Kidd, M. T. (2009). Physiological stress in broilers: Ramifications on nutrient digestibility and responses. Journal of Applied Poultry Research, 18(2), 338-347. doi: 10.3382/japr.2007-00093.

Vlizlo, V. V., Fedoruk, R. S., \& Ratich, I. B. (2012). Laboratorni metodi doslidzhen $\mathrm{u}$ biologii, tvarinnictvi ta veterinarnij medicini: dovidnik (in Ukrainian). 